\title{
V. On the combined action of water and charcoal in oxidizing metals
}

\section{Thomas Gill Esq.}

To cite this article: Thomas Gill Esq. (1815) V. On the combined action of water and charcoal in oxidizing metals, Philosophical Magazine Series 1, 45:201, 23-23, DOI:

10.1080/14786441508638377

To link to this article: http://dx.doi.org/10.1080/14786441508638377

里 Published online: 27 Jul 2009.

Submit your article to this journal $₫$

Џ Article views: 2

Q View related articles $\square$ 


\section{$\left[\begin{array}{ll}23 & ]\end{array}\right.$}

\section{On the combined Action of Water and Charcoal in oxinizing Metaís. By Twomas Gill, Esq.}

\section{To Mr. Tilloch.}

$\mathbf{s}_{\text {IR, }}-\mathrm{A}_{\text {fact stater by Dr. William Henry in the last Num- }}$ ber of 'Thompson's Ammals, of the oxiding of a metal (cast iron) by the combined action of charcoal and steam ; brings to my mind a similar effect which occurred to our ingenious acquaintance Mr. T. T. Hawkins, several year's since; who, in employing powdered charcoal placed between two perforated laden plates, for the purpose of tiltering water, found the water had become considerably impregnated with lead, which led him to take the filtre to pieces, when it appeared that the joint action of the water and charcoal had converted much of the lead into a white oxide, which interspersed with the charcoal, occupied the entire space between the plates, and therefore he was under the necessity of laying them aside, and substituting others in their places not liable to that deiect; by which means he perfectly attained his object, that of employing charcoal as a filtering medium, for which, owing to its great porosity, it is admirably adapted. I an, with much respect, sir,

$$
\begin{gathered}
\text { No. 8:3, St Jtines's Street, } \\
\text { Lomidon, Jam 10, } 13 \text { is. }
\end{gathered}
$$

VI. Account of a Frll of Uranolytes (Aërolites) near Agen. By M. De Sarí Amans*.

$\mathrm{O}$ $\mathrm{N}$ the 5 th of September 1814, a few minutes before mid-day, the wind being nortierly, and the sky perfectly serene, a violeit detonation was heard in the communes of Montpezat; Tenple, Castelmoron, and Montelar, situated in the first, second, and fourth arrondis semens of the department of the Lotand Garonne. This unusual detonation was immeriately followed by three or four others at an interval of half a second successively; and finally, by a rolling mise at tirst resembling a discharge of musketry, afterwards the roling of carritges, and finally, that of a large building falling dowu. These detonations, which tonk place towards the sentre of the department, were heard with more or less intensity within a circle of several leagues. Thus at Agen, four leagues off, they were sufficiently strong to

* Anniles de thinie, tome xivi. p. 25. Oct. 1811.

B 4 